\title{
Broken Lives? \\ Reflections on the Anthropology of Exile \& Repair
}

\author{
David P. Lumsden
}

\begin{abstract}
:
This article provides a rethinking of the concept of' exile' and promotes its utility regarding both the externally and the internallydisplaced. It does so from the perspective of Medical Anthropology. A number of variables affecting and shaping the morality, performance, nature and outcomes of exile are identified. Edward Said's views are discussed; but, must exiles always and forever be viewed or be felt as 'broken lives'? The article argues against a naive presumption of 'universalism' to exile's embodied experience and response; instead, the specificities of cultural meaning systems must be taken into account. Further, it argues against analysts' common presumption of pathology and 'posttraumatic stress disorder' among exiles; instead, evidence for' agency' and 'resilience' in exile populations' health and coping through time must also, and explicitly, be recognized. Finally, where lives are 'broken', the potential of Truth Commissions and 'forgiveness' to be practices of collective repair is noted. Examples are drawn from Africa, Bosnia, Cambodia, Chile, China, Holocaust survivors, and Tibet.
\end{abstract}

\section{Resume}

Cet article propose de repenser Ie concept d" exile', et vise a demontrer son utilite dans Ie cas des personnes deplacees a l'interieur ou a l'exterieur des frontieres. L'approche est

Professor David P. Lumsden teaches in the Department of Anthropology at York University, Canada, and is President of The Toronto-Chongqing Association. celle de l' Anthropologie Medicale. Un certain nombre de variables affectantet configurant les moeurs, la performance, la nature et la quantite des exiles sont identifiees. Les vues d'Edward Said sont discutees; mais on se demande si les exiles doivent toujours et a jamais etre vus et pressentis comme des 'vies brisees'? L' article developpe une argumentation s'opposant a la naIve presomption d"universalite' $\mathrm{du}$ phenomene global de $\mathrm{l}^{\prime}$ experience de l'exil et de la reaction qu'elle engendre. On y affirme qu'il faut plutot tenir compte de la specificite des systemes culture Is de significations. L' article argumente aussi contre la presomption, frequente chez maints analystes, de pathologie ou de 'desordre du a la tension posttraumatique' chez les exiles. Au contraire les manifestation de 'vivacite' et de 'souplesse' dans la santeet l' aptitude des exiles a tenir Ie coup a terme doivent aussi etre reconnues, et ce explicitement. Finalement la ou des vies sont effectivement 'brisees', on observe que les 'commissions de verite' et Ie 'pardon' sont des pratiques de retablissementcollectif dont la portee est notables. Les exemples analyses sont tires du cas de survivants de I'Holocauste, et de ressortissants des pays etcontinents suivants: Afrique, Bosnie, Cambodge, Chili, Chine, et Tibet.

\section{Introduction: Presumptions of Pathology \& Place}

The topic of exile and its consequences is a very common, very timely and very complex matter, only some aspects of which can be addressed in any detail in this paper. I approach the topic from the perspective of Medical Anthropology.
The topic is enriched and haunted by the Jewish experience, both in terms of the Babylonian captivity (e.g., still in the OED- 1964: 424) and especially by the Holocaust and psychotherapeutic misinterpretations and overemphasis of the perceived health consequences thereof. Based usually only on clinical or treatment samples, and largely as viewed through the filters of psychoanalysis, the common psychotherapeutic expectation and interpretation from at least the 1950s on and until quite recently, has been one of mental health and familial problems for survivors- even for subsequent generations. I do not here mean in any simple sense the refugee sociologist Theodor Adorno's assertion (1996: 164) by which "Horror is beyond the reach of psychology" though that perspective alone may be insufficient, or distorting and dehistoricizing. To put the issue very badly, numerous psychiatrists, psychologists and others perceived or claimed pathology and passivity, rather than resilience and agency, in their survivor patients or samples.

Later on, I briefly note the contemporary fixation on, and debatable use of, the diagnosis of "Posttraumatic Stress Disorder' (PTSD), but at this point, the issue I am pointing to is not a minor one for our analytic understanding and practice. If we seek to understand' exile' in all of its variety, or to focus only on enforced displacement and its consequences, we must be careful not to presume only pathology in survivors of 'trauma' -for that then maybe all weare able to 'see' and find, we thereby may well be blind to evidence of resilience in and to transcendence of 'horror'. Resilience and transcendence must always merit our consideration. And we must not just focus, then, on the short-term or immediate emergency period, but rather we must think in terms of, seek data on 
and understanding of- and perhaps help prepare some people for, the longterm. The experience of exile and its consequences, including any health consequences, must be sought within and through a comparative, cross-cultural and longitudinal context and understanding, with respect both to individuals and the cultural collectivity.

Though there now is a growing comparative literature to draw on- perhaps most notably to date, despite my reservation, that concerning Cambodian refugees over time, nevertheless the best available template for our understanding of the longitudinal and international consequences of collective 'traumatic' experience remains that of the Jewish Holocaust and its heirs. Of particular note is the compelling critique by the psychologist Norman Solkoff (1992) of "the presumption of pathology", the ignoring of "the adaptive strategies of survivors and their competence as parents" (cf. Loomis 1998) and the ignoring of "possible steeling effects" for strengthening the survivors' children-and other methodological problems, all to be found in (and undermining the validity of) much recent work by health care professionals and researchers. The two most recent studies known to me about Holocaust survivorship and intergenerational 'transmission' (Sorscher \& Cohen 1997, Yehuda et al. 1998), in my judgement remain subject to Solkoff's methodological critique. Do 'horrific' events inevitably and permanently mark survivors and their heirs? Solkoff's conclusion is edifying for our comparative study-and is cause for due optimism: in general, "children of survivors are not substantially different from other children" (1992: 356).

A second, distorting presumption needs clarification and updating here. To speak boldly and despite the discipline's awareness of inter-cultural borrowings and hybridity, within Anthropology until the last very few years there commonly was a presumption that each culture had its physical 'place' (not mere 'space', but itself a work of culture, becoming 'place'; cf.
Tuan 1977), and thus that if members moved or were dis-placed from that site then, via the move and re-location, their culture would be left behind or lost as they 'acculturated' to the new setting and its dominant culture- and their identities shifting as well.

And further, having gone from place A to place $B$, the movement halted...all this as if for Anthropology, population movementneed necessarily, always, be somehow unusual, abnormal pathological, and linear. Today, of course, we all are concerned with and implicated in a far more 'globalized' and 'simultaneous' system, whose interconnections are more pervasive, intimate, new technology-assisted, speedy and interactive. Culture 'travels' more than ever, its members aremore'diasporic' in nature, its sentiments and memories more multi-sited and moving (Cllifford 1994, Safran 1991, Toloyan 1996). Even exile isn't what it used to be. Today's exiles are but part of a whole World in motion (involving tourists, traders, immigrants, pilgrims, labour migrants, NGO employees, etc.), and the 'place' and experience of exile need not be as out-oftouch with 'home' as may once have been the case and concern-though clearly some constraints may remain (matters of papers and borders: buteven borders can travel, Jansen 1998:98).

The changed world and appreciation thereof is such that the anthropologists Rapport and Dawson recently have argued that "a farmore mobileconception of home should come to the fore...something to be taken along whenever on decamps" (1998: 7). For them, 'home' is not fixedly 'placed'; rather, 'home' is "'where one best knows oneself' - where 'best' means 'most', even if not always 'happiest'". Or again, more fleshed-out in conception, 'home' refers "to that environment (cognitive, affective, physical, somatic, or whatever) in which one best knows oneself, where one's self-identity is best grounded-or worst, or most, or freely, or most presently, as one deems fit" (1998: $9,21)$. Indeed, they argue for great fluidity in or self-placement (1998: 27), for a "recognition that not only can one be at home in movement, but that movement can be one's very home": we thus make our dwelling and express our being through the narration of "moving stories" (1998:30).

The fluidity of their approach is challenging and welcome, yet it clearly begs questions of privilege, differential power, egoistic autonomy and state action. In addition, then, to my underlining of the significance of resilience and transcendence for our appreciation for the narrative and the historical truths of exile, I also in this paper wish to draw attention to an earlier and seemingly rather overlooked consideration of home and 'exile', that of Edward Said, a self-described "American Palestine, an exile" (1992,1998;cf. Arnold 1999), and well-known literary critic.

\section{Exile as an Aesthetic Project}

Said's most extensive 'reflection on exile' remains his very provocative 1984 article, where he defines exile as "the unhealable rift forced between a human being and a native place, between the self and its true home: its essential sadness can never be surmounted" (1984:159: cf. Arendt 1943,70ff.) - this is not a 'fluid' view, but a 'rooted' one (cf. 1984:165), with a tinge of pathology. However, within that same article, Said in fact presents two views or classes of exile. The one speaks of exile as "an anguish" or as "the compounded misery of 'undocumented' people suddenly lost, without a tellable history" (1984: 160,161; cf. Malkki, below); these 'mass' exiles have "broken lives" (1984: 163). From that last phrase comes the title of my own paper, but to which I deliberately add the question mark lacking in Said's reflection on this 'class' of movement.

The second 'exile' is a Foucauldian 'technology of the self' (cf. Lumsden 1996): "provided the exile refuses to sit in the sidelines nursing a wound, there are things to be learned: he or she must cultivate a scrupulous (not indulgent or sulky) subjectivity" (Said 1984: 170: Adorno is his exemplar), achieving thereby the ability to act "as if one were at home wherever one happens to be" (1984: 172). This class of exile is meritorious: such 'scrupulous' exile-selves 
"cross borders, break barriers of thought and experience" (1984: 170). And, as in all of Said's major 'literary' works, he cites the one and the same passage from a twelfth-century monk (on whom, see Luscombe 1972) - part of Said's Christian heritage- as warrant that the highest moral worth attaches to one's achieving of a detachment from all'place'. For, "Seeing 'the entire world as a foreign land' makes possible originality of vision" (1984: 171-172, cf. Appelfeld,1998:197), i.e., a contrapuntal' mode of double consciousness. This more elevated, even 'spiritual', class of exile is more 'elite' in its potential membership: it is a cosmopolitan, scrupulously 'intellectual' elite composed, I suspect, of poets and writers, of Said writ large. For these, exile can be an aesthetic- even ascetic, project and mode of being. I borrow from Said's thought to help illuminate cases below.

\section{Other Faces of Exile}

A number of 'faces' or more prosaic types of exile can be distinguished. Exile may be voluntary or involuntary, self-imposed or other-imposed, and may be near or far, short-term or longterm or permanent. It may be the experience of an individual of a family or of a collectivity (such as an identified political group or an ethnic group), and that exile may be inherited by the next generation or more, perhaps constructing their lives and outlook in varying ways and degrees with 'myths of homeland and return' (Safran 1991, cf. Clifford 1994). Or, a group's exile may be'aborted' or cut short-at least for this time round, and its physical return hastened and nurtured by external playersas with the Kosovar case now messily unfolding. I want to speak somewhat more fully about five other faces of exile: external/internal, proper/improper, fraudulent exilic identities or claims, those left behind, and returnees.

\section{External/Internal Exile}

"Ex-" indicates 'out' or 'from' place, as opposed to those remaining 'in'. In the fields of Refugee Law and Refugee Studies, whether some one or group has left and crossed over a recognized bor- der' helps construct a distinction and differential rights-and perhaps futures, between 'refugees' and those 'internally displaced' (IDPs)- a legal and humanitarian gap thankfully now closing, not least thanks to the anthropologist Francis Mading Deng (1998, cf. L:ee 1996). Exiles, then, may be outside of or still inside of 'their' state boundaries. Just as there are various reasons or pushes \& pulls for external exile, so too there are several forms of internal exile or 'inexile' (Weschler 1998a,:164, 213). And indeed, a particular 'cause' or event may well produce both a population of external exiles as well as a population of internal ones.

Forms of internal exile vary in severity, duration and meaning, not least. Internal 'exile' may come about owing to 'natural' disasters (famine, flood), to the effects of the Dam or other state 'development' projects (Lumsden 1993), to political banishment to that state's version of a gulag or one thinks here of that decade or more thanks to and in aide of Mao Zedong's Cultural Revolution, to one's (dis)embodiment under the statesponsored torture (Weschler 1998a: 213), to civil strife and flight within the state, to being physically in, but not of one's own society as it is currently run. This last form is exemplified, if not among Toronto's homeless, then certainly by the Chilean scholar Helia Lopez Zargosa, whose daily and mental lives were acutely transformed by the military coup of 1973:

"My political exile started long before I was forced to leave my country...After 11 September 1973, I became part of the defeated sector of Chilean society. Our political creeds, ideologies, values, ways of life, everything we believed in, were devalued and stigmatized. Our meaning had been defeated and had been replaced by the new order. I was left deprived of any social value." (1998: 189)

And later she adds, "Chile was my country of origin but ceased to be my home", (1998: 190, cf. 193,198). This example serves to remind us that 'exile' is not a matter of mere self- or group- movement, but rather intimately implicates meaning systems, moral worlds, cultural symbols and concerns, and subjectivity.

\section{Proper/Improper Exiles}

It may seem strange to consider a distinction or binary opposition between 'proper' and 'improper' exiles and exilic behavior, but in fact 'exile' is a social role, one scripted not only by local cultural conventions but also by the desires of potential sponsors or hostlands, by the expectations of humanitarian organizations (cf. Malkki 1996) and by international media (Kleinman \& Kleinman 1997) - not always to the benefit of the 'object' of concern.

Some groups of involuntary exiles arejudges more media-worthy or sponsor-worthy than others: this is not a fair process, nor is it one based on a simple calculus of differential risk or suffering. The fate of particular groups of exiles comes in and out of 'fashion', for complex or crude reasons not effectively within their own control. Thus, e.g., Canada and its allies have been welcoming into their hostland thousands of Kosovar Muslims-who are white, but at roughly the same time Canada did not reach out to assist and welcome exiles caught up in Sierra Leone's very sever civil strife and dis-placement (cf. Thompson 1999), exiles who are not white... and this despite a genuine, historical link between Nova Scotia and the founders of Freetown since the late $18^{\text {th }}$-century (e.g., Walker 1992)-a link emotionally reaffirmed by a diasporic pilgrimage from Nova Scotia in 1992. Or, some groups may find hostland acceptance owing to the 'romance' of their perceived struggle- as Lopez Zargosa has pointed out (1998: 192) regarding "the Latin America guerrillero" in and for France. A similar romance assisted the welcoming of post-'Tiananmen' (1989) Chinese political exiles I both France and the United States, a romance made more salient and successful in this particular case not just because of the presence of a large number of international media in Beijing at the time (to coverGorbachev's visit), but thanks to a 
number of Beijing students ably playing to highly valiant and 'proper' symbols of hostland national identity. Thus the Beijing student demonstrations not only appealed internally to the $70^{\text {th }}$ anniversary of China's May Fourth Movement but also knowingly took place at a time marking the $200^{\text {th }}$ anniversary of the French Revolution, while an icon erected in Tiananmen Square was the 'Goddess of Democracy', evocative of the Statue of Liberty (itself, of course, a gift to the U.S. from France...)! On a far less successful note, I myself have keen memories of debating with some Liberian refugees in Waterloo Camp, Sierra Leone, in 1993, as to why Bosnia and not their case was then in fashion in the West.

Particular symbolic weight and cultural pressure may be placed on exiles', or certain categories', moral or sexual conduct. Helia Lopez Zargosa, e.g., reports her experience as the wife of a Chilean political prisoner. On the other hand (1998: 190), there was an experienced enhancement of gender awareness and accomplishment: "Men became isolated and dependant in prison, while women were forced to take on the 'father / husband' roles. In so doing, we became self-reliant and independent; 'masculine' traits which reinforced our female worth, and were a source of pride". On the other hand, given "the glorification of the political prisoners" in her circle, "We had to keep the positive image of being the wife of a 'hero' and behave accordingly... political prisoners' wives... were under string social pressure to maintain their husband's 'honour' and would be severely punished if they were to transgress these social values" (1998: 190-191). Marriages do not always survive such cultural forces- as with Lopez Zargosa's own later 'abandonment' while in external exile.

Similar pressures by the exile community on its heroes' marital conduct or sexual adventures have been noted among host-'Tiananmen' Chinese 'democracy' leaders (Ma 1993: 380-381). And their engagement with mainstream business activities while in Western exilehas also been regarded by fellow exiles as improper conduct, conduct suggesting a decreasing commitment to 'the cause' while also undermining the credibility of their leadership and the moral purity of their roles. Hence, e.g., the harsh criticisms of the quite successful U.S. career of Ms. Chai Ling and Mr. Li Lu, particularly around the tenth anniversary of 'Tiananmen' earlier this month (Burma 1999, Mickleburgh 1999, Wong 1999, cf, Cohn 1999; on Wu'er Kaixi's decline, see Schell 1994). Similarly too, the Burndi Hutu in the refugee camp studied by Malkki (1995- discussed further below) strongly disapproved of the 'improper' - indeed 'disloyal', marital (in this case, inter-marriage with Tanzanians) and entrepreneurial activities of the Hutu town-based 'exiles'.

There is then, a cultural code of conduct (a 'scrupulosity' to use Said's phrasing, or an ascetic 'technology of the self'. to use Foucault's) for properly playing the role of 'exile' even more so for exilic leaders, and a price to be paid for impropriety. Refugee agency or camp administrators, have, and act on, their images of pure/impure 'refugeeness' as well, as Malkki documents (1996: 382-385).

\section{The Fraudulent Exile}

The exile status and 'career', with its sometimes evocative pathos and other potential seductions, on rare occasions has attracted fraud- with resulting hurt to persons and/or causes. I present three recent cases:

In one case, a man claiming the identity of a Binjamin Wilkomirski recently published a best-selling book called, Fragments: Memories of a Wartime Childhood, concerning the WWII traumata of his concentration camp life and of his later Swiss fosterage, a work now revealed as but a pastiche of researched lies, indeed as the work of a non-Jew, a case bitingly characterized as the work of a 'memory thief' (Gourevitch 1999). It seems to me to have been deliberate fictioneering, and not the 'false memory syndrome' suggested by another critic (Pendergrast 1999).

The second case is that of a genuine WWII concentration camp dweller who went on to a highly successful career in the U.S. as an 'expert' on the psychology of concentration camp survivors/refugees, as an acclaimed child psychotherapist-i.e., Bruno Bettelheim (Pollak 1997, cf. Arednt 1943: 73), who was revealed after his 1990 suicide, built a career on exaggerated or fraudulent professional claims and who, besides, seemingly was a bully and abuser of the very children in his charge.

The third case involves the winner of the 1992 Nobel Peace Prize, Mayan woman, Rigoberta Menchu, an international icon, thanks to her best-selling 'autobiography', of the indigenous struggle to overcome the three decades of violence and displacement affecting hundreds of thousands of Guatemalans. Yet as the anthropologist David Stoll now rather reluctantly reveals (1999, cf. also Canby 1999), her narrative is erroneous or untruthful in parts, is not the 'pure' eyewitness account first claimed and which attracted so many supporters.

In the Wilkommerski and Menchu cases, debates continue to gather steam over such questions as: can something untruthful, nevertheless speak to truth? whose truth about violence and exile should be listened to or commemorated?, whose 'memories' claim history? And more (e.g. Ozick, 1999).

\section{Those Left Behind}

Exiles arenot likely to moveneatly packaged with all the kin and others they hold dear; it is important to note the distinction between exiles and their support group safely present with them or safely in one or more hostlands, and the case of exiles being haunted by the letters, phone calls, faxes, e-mails or spirits of those whom they had to or did leave behind (e.g. Eisenburch 1990, Wein etal.1995). This last case may constrain exiles' conduct and political activities in the hostland and diasporafor fear their loved ones may easily be punished in their stead and/or may encourage their yearning and action to 'return'. Or, exiles though their remittances 'home', may send back support to those left behind, thereby perhaps also helping to maintain in power the 
very regime they themselves fled. Or, external exiles consciously or unconsciously may choose to 'forget' their parents or others left behind, in favour of making a new life (and new memories) for themselves or for their children in the hostland (see Weine et al.1997 for a Bosnian Muslim case in the U.S.; cf. Kenkins 1997:41). Or, the exile's culture or religious tradition may provide meaningful symbolic or ritual ways of meritoriously salving cultural expectations and pangs of conscience regarding those 'abandoned'- as in Cambodian Buddhism's mechanism for living or deceased parents, for the latter's next life.

\section{Returnees}

Another face of exile are exiles who return, or who are returned, to their homeland, which by then has changed or has or which soon undergoes significant changes with which they must reckon (e.g., Lopez Zargosa 1998, 194, 197, for Chile, and the Godley 1989 for returnees caught up in Mao's Cultural Revolution of 1966 -76). Returning may well not complete the exile's trajectory nor bring resolution. One may return to find perpetrators of one's torture, or those who betrayed you or your family, still walking the streets at their ease (e.g. Weschler 1998a). Or, after being a 'proper' exile and returning, you may find, you must now fend off accusations-drawn from liberated regime files, with their cesspool mix of 'truth' claims- that you were an informer (see the Czech case in Weschler 1998b). Other exiles may simply return for a brief healing closure of sorts, and depart again. After 57 years, e.g., Aharon Appelfeld (1998: 190) felt both the pull and the possibility of return, to the Ukraine:

"An old feeling of guilt, which I had repressed for many years, floated up (in 1996). Its essence was a mass grave in the village of Drajinetz, in which my mother and grandmother were buried. The thought that one day I might stand by that grave in silence would not leave me...

And so, in 1998, he returned, to Cernovitz, where "every street comer reminded me of an outing with my par- ents, a surprising gift" (1998: 191), and then to 'the scene of the crime' (see Ignatieff 1998):

"We stood in silence. Many thoughts raced through my mind, but none that I could grasp. My mother's face, whose features I had preserved for so many years, was suddenly erased from my memory" (Appelfeld 1998: 194)

And later he remarks, in a splendid evocation of 'place', "I had seen where she was buried and what you can see from there" (1998: 197) - and he moves on, goes back to Israel.

\section{Some Key Variables and Social Categories}

To be an exile does not mean- and we must not presume, that there is but one, 'typical' or essentialist life-cycle to be experienced over time, as say from preexile or pre-flight on to encampment or asylum and on to diaspora and/or to return and its aftermath. In addition to the different 'types' I have discussed, there is a diversity of other factors and social categories under the resonant rubric of 'exile', which help shape varying life-trajectories. Moreover, to be an exile of one form or other, may well entail the assumption or discarding of a host of identities (cf. Arendt 1943: 75, 76).

Space precludes my doing littlemore than specifying some of these pregnant variables, and then categories, affecting the nature, resources, resilience and risks, and processes of exilic experience. Important variables include: cultural constructions of selfhood (e.g., egocentric, sociocentric), embodiment, nutrition, emotions and memory, reputation, gender and sexual orientation, age and generation, type of kinship system, class, ethnicity, conceptions of 'home' or 'place', conceptions of health and health care, idioms of distress and their explanatory models (e.g., see Desjarlais et al. 1995, Kleinman 1988), education and communication systems, faith tradition and the meanings and values of life, death and beyond, plus issues of 'cultural bereavement' (Eisenbruch 1990), as well as exposure or not to encampment and all its issues, and/or the supportivenature, or not, of a host-land or diasporic community.

In understanding and analyzing exile trajectories- or in trying to assist in refugeecamps or resettlement agencies, there are a number of social categories of persons and roles which may carry special resilience / risk differentials or special cultural weight for good or ill outcomes, and which therefore are well worth according culturally-sensitive consideration. All these must be approached with a presumption of resilience and agency, not just with one of symptomatology. These social categories include: single women and household heads in exile (Women's Commission/UNHCR), widows, victims of rape and collective dishonour, children of such rape (unless abortedas among some of Kosovar refugees: Ward 1999), unaccompanied children and war orphans, child soldiers of all sides (said by UNICEF to now total some 300,000 persons under the age of 18 : The Economist 1998), those in mixed marriages in situations of inter-ethnic conflict, those totally abandoned or feeling so, perpetrators and victims/heroes of torture or atrocity, the disabled, the ill (as from communicable disorders in camps, etc.), those newly dis-placed, newly resettled or returned, those facing prejudice and discrimination in their new hostland (e.g., Cambodian refugees in Ontario, especially it seems, those in London, Ontario: McLellan 1995), intergenerational difficulties in exile, and not least, those doing extremely well (notjust for lessons in resilience, but because these may be targets of intra-community envy or witchcraft).

Again, the particular cultural aspects of each category in each exile must be ascertained, not assumed as being 'universalistic' or 'generic', nor dehistoricized. Totakebut one example of the complexities hidden in my listing, consider the disabled body in its cultural specificity: the anthropologist Lindsay French has explored the cultural valence accorded loss of limbsowing to landmines, among Cambodian refugees/returnees (1994). This is not a mere matter of obtaining prostheses. In local Buddhist under- 
standing, not to possess a whole body bodes ill for one's next rebirth, and the sense of worth of one's present embodied self is also devalued. Any therapeutic intervention must address this moral construction and stress-load in meaning-full ways. Or consider the various cultural ways and discourses of 'doing de-pression' (psychologized, somatized, etc.: Kleinman \& Good 1985, Kleinman 1988)-which also call for cultural expertise in therapy. And not least, seek to know cultural ways of 'doing resilience' too.

\section{Exile Community Milestones}

In addition to considering the variables and social categories cited above, special attention should be given to exile community life-cycle milestones over time (e.g., significant anniversaries, transitions of office and generation, etc.), which may pose particular challenges to their meaning-system, continuity, and collective resilience.

Togive but oneexample, consider the Tibetan exile, and the spiritual as well as political leadership of the $14^{\text {th }}$ Dalai Lama (Batchelor \& Lopez 1998, Mirsky 1999, Singh 1998). The year 1999 includes the $40^{\text {th }}$ anniversary of the Dalai Lama's flight into Indian exile: how long will an exile community continue to follow a leadership which, after forty years-and years of an insistence on pursuing a non-violent course, has not brought a 'return'closer? A leader, moreover, who in recent years officially has eschewed seeking the totally independenthomeland that so many followers desire? Instead, the Dalai Lama seeks his return and but a limited autonomy for Tibet, whereby Beijing will control the delimited region's foreign affairs and defence: and even so, he has not yet received a formal reply. Further, a leader who recently has alienated several thousand Tibetans in exile by ruling that what some worship as a 'protector deity' is in fact a demon (i.e., Dorje Shugden)-and several murders appear to have ensued from this dogma. This questioning, frustration and division within the exile community is exacerbated by the looming succession crisis when the current Dalai Lama, aged sixty-five, dies-for his reincarnation must be located and accepted, and China clearly intends to have a say therein. Might not there then be two rival Dalai Lamas, as there now seem to be rival Panchen Lamas? What does this augur for the exile communities solidarity and well-being, let alone that of Tibet? In the meantime, China waits, and ponders the 'return' of Taiwan.

\section{The Role of Time}

Time is, in fact, one of the key variables in understanding and in experiencing exile. As time passes, there may well be constructed a more or less tolerable accommodation to, or exercise in creativity within, exile-nor does the homeland stand still. There is an old saying within my tradition, that time heals-or at least other distractions or enticements arise. If there was symptomatology in the early months or first phase of exile, then such distress may well decline, become but background noise, or disappear in a relatively short period of time.

Indeed, in Weine et al.'s (1997) therapeutic transaction with one Bosnian Muslim family, e.g., it is striking to note that on their first arriving in the U.S., all four members were diagnosed as displaying "severe PTSD and impaired social functioning"; yet "after one year there were minimal trauma-related symptoms and no diagnosable psychiatric conditions among all the family members" (1997:34). Or, note the case of Tibetan child exiles in India (ServanSchreiber et al. 1998:78): after 18 months since their arrival, the perceived rates of both PTSDand Major Depression began to drop away. Again we see the vital importance of following exiles over time, and of not presuming inevitable, permanent pathology: it is important to take time and the local phases of exile into account.

Another aspect of this is the cultural construction of 'time': e.g., is time itself moving in a linear or a cyclical path? Consider the case of the Tibetan Buddhist children assessed by ServanSchreiber et al. (1998). Here the belief in the cycle of rebirth is important for understanding how some 'coped with' or interpreted away and transcended 'trauma': present suffering may imply future happiness:

"Several subjects mentioned that the traumatic events they had experienced were related to their 'karma' and that they now had paid their karmic debt. They believed that this would free them to enjoy a happier life from this point into the future" (1998: 879).

Time, Memory, and the PTSD Fad

Currently, the most popular diagnosis in use with patients or populations who are involuntary exiles is that of PTSD. This is a diagnosis which intimately entails cultural beliefs about selfhood and emotions (e.g., the perception of "a threat to the physical integrity of self or others, your response involving "intense fear, helplessness, or horror": American Psychiatric Association / APA 1994: 52-53), and about time and memory (e.g., "recurrent and intrusive distressing recollections of the event", even "inability to recall an important aspect of the trauma": APA 1994: 51).

The diagnosis entered the APA's Diagnostic and Statistical Manual of Mental Disorders only in its 1980 Third Edition (or DSM-III), and only as a result of persistent lobbying by U.S. Vietnam War veterans and insurance companies. Its use since has been expanded to apply to a very heterogeneous assortment of 'traumata' (and Weine et al. are willing to expand it further: 1995: 536), whose meaningfulness to those experiencing or exposed to such an event implicates culture as well. The present diagnostic criteria set for this disorder ('event' in time and memory, emotion, as well as 'reexperiencing', 'avoidance' and 'hyperarousal' symptom clusters, etc.) can be found in the DSM-IV (APA 1994), and a consideration of the disorder's 'invention' can be found in the McGill anthropologist Allan Young's recent book (1995; for a psychiatric perspective on PTSD's genealogy, see Kinzie \& Goetz 1996).

There are a number of troubling issues about this diagnosis and its location of pathology; my sketch of these must be brief, and I must underline that 
research and debate continue: and such controversy is 'healthy'.

(1)The construct seems 'culturebound'; it very much draws on mainstream North American presumptions of egocentric selfhoodand on the current cultural overemphasis here on 'victimhood' rather than resilience.

(2)Its use sometimes rests only on clinical or treatment or referral samples-not on general community or 'true prevalence' ones, thereby biasing conclusions towards pathology.

(3) It is clear that symptoms and lifenarratives can be manipulated by 'patients' so as to receive or keep this diagnosis, doing so in order to have access to certain benefits : e.g., see Young 1990.

(4) Its use, even in North American populations, may overly fixate on 'the event' as 'cause' while completely failing to investigate the role of pre-event personality traits, and cultural beliefs; this failure is particularly sharp, for it may otherwise help explain who 'gets' PTSD when most do not (Bowan 1997, cf. APA 1994,5152).

(5) Its use may overly personalize life-events, focus only on the particular patient shorn of context, by ignoring the collective experience and collective, cultural meanings.

(6) Its use may overly or inappropriately 'medicalize' life-events, which should more meaningfullybe seen as political and moral issues requiring moral resolutions more than biomedical interventions (cf. Weschler 1998a:240-241): i.e., its use can dehistoricize and depoliticize involuntary exile-and heroism, ignoring the nature of the event in favour of 'symptoms' (Kleinman 18998, Malkki 1996; but Sack et al. would disagree: 1997: 53-54).

(7) Further, where PTSD us diagnosed, the fact that most of the persons undergoing that 'event' do not, or soon do not, display PTSD also needs to be explained; otherwise, individual and collective resilience, hardiness or courage (as culturally formulated) are scanted or ignored, not checked for (cf. Solkoff 1992, as discussed earlier). In Servan-
Schreiber et al. (1998), only $11.5 \%$ of the 61 Tibetan child exiles 'had' PTSD (assuming they understood the questions), more so in males, while another $11.5 \%$ 'had' major depressive disorder (more so in females-suggesting cultural gender scripts for symptomatology); that team 'suspects' higher real caseness, but at least they do try to identify-and accept, cultural 'protective' factors.

(8) PTSD's validity for use in crosscultural contexts-or with multi-cultural patient populations here, is contested (see, e.g., Friedman \& Jaranson 1994, Marsella et al. 1996, Mears \& Chowdhury 1994, 45, Sacket al.1997); what are the norms or standards for cross-cultural use and credibility with children, adolescents or adults?-Servan-Schreiber et al. (1998: 878) and Mollica et al. (1997: 1104) admit the lack of such validity in their studies of Tibetan children and Cambodian adolescents, respectively.

(9)The use of Western-based assessment instruments may not only be invalid cross-culturally, but also may not capture, not look for nor listen for, culturally-salient experiences and concerns of the particular population. To help address this problem, the anthropologist-paediatrician Maurice Eisenbruch (1990) has developed a 'cultural bereavement interview' schedule for Cambodian refugees (and perhaps, with modifications, for other groups), one which does seek out and capture more of their local idioms of distress than does DSM-IV, say-yet his schedule too, used alone, seems to me to risk over-pathologizing (and cf. Sack et al.'s critique: 1997: 53).

(10) Finally, one sometimes gets the sense that Western health professionals are so wedded to the PTSD explanatory model that, even when their own data show most of their target population are indeed enjoying 'positive' social and/or school or occupational'functioning' in society, they nevertheless still insist on the population requiring 'treatment' or 'preventative' intervention: i.e., they render resilience suspect (e.g., Mollica et al. 1997: 1105, cf.1104, and Sack et al. 1995: 179-180, 181: both regarding Cambodian adolescent samples). The specific examples I cite also seem to 'forget' that DSM-IV itself (APA 1994, 54) would not permit such disregard: for DMS-IV, the PTSD diagnosis should only be given if there is evidence for "clinically significant distress or impairment in social, occupational or other important distress of functioning". To be blunt, this suggests that, where societal functioning is 'positive' and sufficient, there in no 'need' for biomedical intrusion (unless it's 'makework'?): let such exiles move-on in their lives. And this brings me to my second-last section or topic, that of the 'creativity' of exile.

\section{Exile as Creativity}

I present two cases of the creativity of exile, one the case of an individual, and one of a group. There is some truth in Theodor Adorno's remark (1996: 87) that, "For a man who no longer has a homeland, writing becomes a place to live". A case in point (aside from Said's own life) is that of the Israeli-based author, Aharon Applefeld $\backslash$, a case documenting the creativity that may flow from, be stimulated by, forced dis-placement, years of exile, and reflections on 'home' memories (1998: 188):

"I was driven away from home (in 1941) at the age of eight and a half. What does a child of eight and a half remember? Almost nothing. But, miraculously, that 'almost nothing' has nourished me for years. Not a day passes when I'm not at home. In my adopted country of Israel, I have written thirty books that draw directly or indirectly upon the (Ukrainian) village of my childhood, whose name is found only on ordnance maps. That 'almost nothing' is the well form which I draw and draw, and there seems that there is no end to its waters".

Hehas achieved tremendouscreativity, social functioning and international acclaim in the 57 years following dis-placement. And he has done so despite (and partly because of?) his years of 'sleep disturbance': he reports of the 1941 slaughter of Jewish villagers, "Shouts and sobs filled the village for two days, and they continue to arouse me from my sleep", "the sob of the slaughter" (1998: 188, 192). Should he 
be medicalized, or applauded and learned from?

The second case, available through the anthropologist Lisa Malkki's work, is fascinating: she studied Burundi Hutu in 'exile' in Tanzania, doing so about 14 or 15 years after 1972 massacres. Her study design provides us with insight into the role of culture, time and memory in two populations of Burundi Hutu. The 35,000 or so Hutu dwelling in the isolated and regulated refugee camp of Mishamo, and the Hutu living some $200 \mathrm{~km}$ away in the town of Kigoma- part of the 20,000 or so Hutu said to be in that region. So two types of 'exile' are documented for the one and the same ethnic group, both having lived through the one and the 'same' horrific events- but it should be noted that most of her study respondents were, or had to be, males (1995: 50-51, 178).

The striking difference between these two populations of Hutu is for the Mishamo camp inhabitants, 'exile' and keeping their participation in it 'pure' and strong was the key to their identity as 'a people' or indeed as 'a nation' awaiting its due 'return' to Burundi, via their creation and dissemination of the 'mythico-historical' narratives- "a grand moral historical vision" (1995: 104), a culturally-constructed and solidifying, heroic 'memory'. For them, being a 'refugee' was a cultural process of becoming, was positively valued and was accompanied by an emphasis on demonizing 'the Tutsi' as a collectivity who did not have moral nor even historical claim to the place of Burundi. For the Mishamo Hutu, if they worked at being 'pure', they would be worthy of return and, alas, of triumph back 'home' (i.e., their creativity is therapeutic for them, but sets the stage for future revenge and a cycle of violence).

In contrast, the town-based Hutu did not want to identify their selves as 'Hutu', not as being 'refugees', nor as being in 'exile'. Rather, they pursued several ways to conceal or nullify their Hutu origins, to be economically successful in Tanzania, and to stay there: for most, it was 'an open question' as to whether they would ever return to
Burundi (1995: 183). These Kigoma Hutu intermarried with the Ha of Tanzania, or even presented themselves as being Muslim (vs. the Catholic or Pentecostal identities of the Mishamo and Burundi Hutu), or claimed to be Tanzanian 'citizens'- or even obtained such legal status. These Hutu were focused on their individual, situational or pragmatic identity versus the Mishamo inhabitants' emphasis on their collective identity. The Kigoma Hutu feared being put into a refugee camp; for the Mishamo Hutu, the town Hutu were most improper or impure, being set against the intermarriage and commerce that attracted town-dwellers, distracting the latter from 'the cause'. For Mishamo Hutu, "exile was conceived as a perpetual present" (1995: 188), on awaiting "a millennial return", awaiting "reclaiming the nation" (1995:188, 191). For the Kigoma 'Hutu', the past was not alive, the past "had simply passed" (1995: 194) and they had pragmatically moved on. The Mishamo Hutu had not forgotten, not forgiven.

Though Malikki cites three works by Said, his 1984 paper on 'exile' is not referred to; yet it seems to me clear that her Mishamo camp Hutu well fit Said's discussion of the links between exile and what he terms "defensivenationalism", they have constructed "a national history" (which they do tell, vs. Said 1984), 160 perhaps), and they were promoting a "strident ethnocentrism" which was both their political and their therapeutic practice, just as feeling part of "a nation's struggle against an oppressor" was being both political, moral, spiritual and even therapeutic (and bio-medical) for Tibetan child exiles (Servan-Schreiber et al. 1998: 878879).

One last topic remains for this paper.

\section{Repair, If Broken}

There are a number of mechanisms or practices for repairing cases and times where exile has 'broken lives', has broken a cultural collectivity. One is by commemorating the event, the 'disappeared' and/or the survivors' courage and resilience, in a concrete and public way, with appropriate ritual: i.e., as through placing monuments, museums (e.g., the recentcontestation over a Holocaust gallery or museums for Ottawa, the steps towards a Holocaust museum in Berlin, etc.) or other public rites of 'memory'. A second mechanism is to pursue 'justice' through the political, legal and perhaps therapeutic holding of 'war crimes' trials- as in the steps towards an International Criminal Court. A third technology of collective repair, is for the new civilian regime to establish a pursuit of 'truth' rather than of 'justice'- for perhaps otherwise the military may feel a call to 'return'. A number of societies recently have held such Truth commissions: one thinks of Chile, or South Africa's remarkable Truth and Reconciliation Commission, under Archbishop (and Nobel Prize winner) Desmond Tutu- a leadership which underlines the moral or spiritual, rather that legal, purpose, of Guatemala's Recovery of HistoricalMemory Project (whose founder, Bishop Juan Gerardi, was assassinated right after the report's submission: Goldman 1999) and its separate, UN-backed Truth Commission. These can provide healing narratives, some moral vindication for the collectivity; but not all such societies have taken that step-how will Cambodia's president regime seek resolution if not what some call 'closure' (e.g., The Economist 1999)?

Another, moral and difficult path or technology is that of individual and collective 'forgiveness' (not necessarily followed by 'forgetting'), and I am interested in what may be called the Anthropology of Forgiveness. Weschler (1998a) has tackled the topic, regarding Brazil and especially Uruguay, and not Applefeld's report on today's Ukraine (1998: 195). But for me, the most resonant and challenging effort to lay bare the moral complexities entailed, is that by the Holocaust survivor and Nazihunter, Simon Wiesenthal. Icommend to your attention, and reflection, the 1998 edition of his treatise on, The Sunflower: On the Possibilities and Limits of Forgiveness, which now comes with 53 short commentaries by an international cast, this including the 14the Dalai Lama. I will not spoil you reading

Refuge, Vol. 18, No. 4 (November 1999) 
by giving full details ofWiesenthal' $s$ encounter with a dying Nazi soldier during WWII, about what Wiesenthal did and did not do during both that episode and his subsequent visit to the man's mother. The soldier participated in an atrocity of the Jews of a particular town, endeavours to 'confess' to Wiesenthal, and the outcome troubles Wiesenthal down to today: "was my silence at the bedside of the dying Nazi right or wrong?" (1998:97). Isforgivenessmorally right and even possible? Who can forgive whom, and how? And when?

This narrative allows me to end this paper underlining the theme of the central importance of morality- a work of culture and conscience and choice. I have explored the many dimensions of exile, and challenge you to reflect on culture and morality, on time and memory, on resilience and agency and courage, and challenge you to avoid the presumption of pathology. The exilic project and its truths- and its triumphs and heartbreaks, cannot be grasped through Biomedicine or Psychology alone. Listen to, reflect on, exile, in our global village in motion. II

\section{References}

Adorno, Theodor.1996.MinimaMoralia: Reflections from Damaged Life. London/New York: Verso.

American Psychiatric Association. 1994. Diagnostic and Statistical Manual of Mental Disorders, Fourth Edition (DSM-IV). Washington.

Appelfeld, Aharon. 1998. "Buried Homeland." The New Yorker, November 23, 1998: 188197.

Arendt, Hannah, 1943. "We Refugees." The Menorah Journal 31 (1) : 69-77.

Arnold, Michael. 1999. "What Said Said." Lingua franca 9 (4): 8-9.

Barber, Ben. 1997. "FeedingRefugees,orWar" The Dilemma of Humani tarian Aid." Foreign Affairs 76 (4), :8-14.

Batchelor, Stephen \& Donald Lopez. 1998. "Deity or Demon? The Controversy Over Tibet's DorjeShugden." Tricycle, 7 (3): 5882.
Bowman, Marilyn. 1997. Individual Differences in Posttraumatic Response. London/New Jersey: Lawrence Erlbaum Associates.

Buruma, Ian. 1999. "Tiananmen, Inc." The New Yorker, May 31, 1999: 45-52.

Canby, Peter. 1999. "The Truth About Rigoberta Menchu." The New York Review of Books, XL VI (6): 28-33.

Clifford, James. 1994. "Diasporas." Cultural Anthropology, 9 (3): 302-338.

Cohn, Martin Regg. 1999. "Security forces cordon off Tiananmen." The Toronto Star, June 5, 1991, A27.

Deng, Francis Mading. 1998. Guiding Principles on Internal Displacement. United Nations/ OCHA, 14

Desjarlais, Robert, et al. 1995. World Mental Health. Oxford University Press.

The Economist. 1998. "Under-age Killers." The Economist, December 12, 1998: 46.

The Economist. 1999. "Atlast, a trial of sorts in Cambodia." The Economist, June 12, 1999: 36.

Eisenbruch, Maurice. 1990. "The Cultural Bereavement Interview: A New Clinical Research Approach for Refugees." Psychiatric Clinics of North America, 13 (4): 715735.

French, Lindsay. 1994. "The political econom y of injury and compassion: amputees on the Thai-Cambodia border." In Embodiment and Experience, edited by Thomas Csordas. Cambridge University Press, 6999.

Friedman, Matthew andJamesJaranson. 1994.

"The Applicability of the Posttraumatic Stress Disorder Concept to Refugees." In Amidst Peril and Pain, edited by Anthony Marsella et al., 207-277. Washington: American Psychological Association.

Godley, Michael. 1989. "The Sojourners: Returned Overseas Chinese in the People's Republic of China."Pacific Affairs, 62 (3): 330-352.

Goldman, Francisco. 1999. "Murder Comes for the Bishop." The New Yorker, March 15, 1999: 60-77.

Gourevitch,Philip. 1999. "TheMemoryThief." The New Yorker, June 14, 1999: 48-68.

Ignatieff, Michael. 1998. "The Scene of the Crime". Granta, 63: 122-149.

Jansen, Stef. 1998. "Homeless at Home: Narrations of Post-Yugoslav Identities". In
Migrants of Identity, edited by Nigel Rapport and Andrew Dawson, 85-109. Oxford: Berg.

Jenkins, Janis. 1997. "Not Without a Trace:

Resilience and Remembering (Commentary)". Psychiatry, 60 (1): 40-43.

Kinzie, J. David and Rupert Goetz. 1966. "A Century of Controversy Surrounding Posttraumatic Stress-Spectrum Syndromes: The Impact on DSM-III and DSMIV". Journal of Traumatic Stress, 9 (2): 159-179.

Klienman, Arthur. 1988. Rethinking Psychiatry. New York: Free Press.

Kleinman, Arthur and Byron Good, editors. 1985. Culture and Depression. Berkeley: University of California Press.

Kleinman, Arthur and Joan Klienman. 1997. "The Appeal ofExperience, The Dismay of Images: Cultural Appropriations of Suffering in Our Times". In Social Suffering, edited by Arthur Kleinman et al., 1-23. Berkeley: University of California Press.

Lee, Luke. 1996. "Internally Displaced Persons and Refugees: Toward a Legal Synthesis?" Journal of Refugee Studies, 9 (1): 27-42.

Loomis, Carol. 1998. "Everything in History was Against them". Fortune, April 13, 1998: 64-85.

Lopez Zargosa, Helia. 1998. "Internal Exile, Exile and Return: A Gendered View". Journal of Refugee Studies, 11 (2): 189-198.

Lumsden, David Paul. 1993. Dams, Dis-Placement,andMindfuIDistress. Working Paper Series on International and Behavioural Health. Centre for the Study of Culture and Medicine/Program in Medical Anthropology. Cambridge: Harvard University, 69.

Lumsden, David Paul. 1996. "Theories voyageuses. Foucault, Grant, la Chine et al regionalisation des soins de sante." Anthropologieand Societies, 20 (1): 27-58.

Luscombe, David. 1972. "Saint Victor, School of." In The Encyclopedia of Philosophy, edited by Paul Edwards, 7, 277-278. London: Collier-Macmillan.

MaShu-Yun.1993. "TheExit, Voice and Struggle to Return of Chinese Political Exiles." Pacific Affairs, 66 (3): 368-385.

Malkki, Liisa. 1995. Purity and Exile: Violence, Memory and National Cosmology among Hutu Refugees in Tanzania. Chicago" The University of Chicago Press.

Malkki, Liisa. 1996. "Speechless Emissaries: Refugees, Humanitarianism, and Dehistoricization." Cultural Anthropology, 11 (3): 377-404.

Refuge, Vo1.18,No.4 (November 1999) 
Marsell, Anthony, et al., editors. 1996. Ethnocultural Aspects of Post-Traumatic Stress Disorder. American Psychological Association.

McLellan, Janet. 1995. Cambodian Refugees in Ontario: An Evaluation of Resettlement and Adaptation. Toronto: York Lanes Press.

Mears, Catherine and Sue Chowdhury. 1994 Health Carefor Refugees and Displaced People. UK: Oxfam.

Mickleburgh, Rod. 1999. "Revolutionaries scattered in a world of guilt." The Globe and Mail, June 3, 1999, A22.

Mirsky, Jonathan. 1999. "The Dalai Lama on Succession and on the CIA". The New York Review of Books, XLVI (10): 48-49.

Mollica, Richard, et al. 1997. "Effects of War Trauma on Cambodian Refugee Adolescents' Functional Health and Mental Health Status". Journal of the American Academy of Child \& Adolescent Psychiatry, 36 (8): 1098-1106.

Oxford English Dictionary (OED). 1964. The Concise Oxford Dictionary of Current English. Oxford: Clarendon Press.

Ozick, Cynthia. 1999. “The Rights of History and the Rights of Imagination." Commentary, 107 (3): 22-27.

Pendergrast, Mark, 1999. "Holocaust Hoax". LM(Living Marxism), 118, March, 1999:2628.

Pollak, Richard. 1997. The Creation of Dr. B: A Biography of Bruno Bettelheim. New York: Simon and Schuster.

Rapport, Nigel and Andrew Dawson, editors. 1998. Migrants of dentity: Perceptions of Home in a World of Movement. Oxford: Berg.

Sack, William, et al.1995. "The Khmer Adolescent Project, II: Functional Capacities of Two Generations of Cambodian Refugees". The Journal of Nervous and Mental Disease, 183 (3): 177-181.

Sack, William, et al. 1997. "Does PTSD Transcend Cultural Barriers? A Study from the Khmer Adolescent Refugee Project". Journal of the American Academy of Child and Adolescent Psychiatry, 36 (1): 49-54.

Safran, William. 1991. Diasporas in Modern Societies: Myths of Homeland and Return." Diaspora, 1 (1): 83-99.

Said, Edward. 1984. "Reflections on Exile." Granta, 13: 158-172.

Said, Edward. 1992. "Palestine, Then and Now: An Exile's Journey Through Israel and the Occupied Territories". Harper's Magazine, 285 (1711): 47-55.

Said, Edward. 1998. "Between Worlds". London Review of Books, 20 (9), 7 May, 1998: 3 , 5-7.
Schell, Orville. 1994. "Exile Dreams". In his Mandate of Heaven,437-441. New York: Simon \& Schuster.

Servan-Schreiber, David, et al., 1998. "Prevalence of Posttraumatic Stress Disorder and Major Depressive Disorder in Tibetan Refugee Children".Journal of the American Academy of Child \& Adolescent Psychiatry. 37 (8): 874-879.

Singh, Ajay. 1998. "Fires of Frustration". Asiaweek, 24 (36), September 11, 1998: 52 56.

Solkoff, Norman. 1992. "Children of Survivors of theNazi Holocaust: A Critical Review of the Literature". American Journal of Orthopsychiatry, 62 (3): 342-358.

Sorscher, Nechama and Lisa Cohen. 1997. "Trauma in Children of Holocaust Survivors: Transgenerational Effects". American Journal of Orthopsychiatry, 67 (3) :493-500.

Stoll, David. 1999. Rigoberta Menchu and the Story of all Poor Guatemalans. Boulder: Westview Press.

Thompson, Allan. 1999. "Sierra Leone now a 'forgotten crisis'". The Toronto Star, May 12, 1999, A7.

Tololyan, Kachig. 1996."Rethinking Diaspora (s): Stateless power in the Transnational Moment." Diaspora, 5 (1): 3-35.

Tuan Yi-Fu. 1977. Space and Place: The Perspective of Experience. Minneapolis: University of Minnesota Press.

Walker, James St. G. 1992 The Black Loyalists: The Search for a Promised Land in Nova Scotia and Sierra Leone, 1783-1870. The University of Toronto Press, reprint series.

Ward, Olivia. 1999. "The silent horror of Kosovo: Rape". The Toronto Star, June 2, 1999, A1 and A21.

Weine, Stevan, etal. 1995. "Psychiatric Consequences of 'Ethnic Cleansing': Clinical Assessments and Trauma Testimonies of Newly Resettled Bosnian Refugees". American Journal of Psychiatry, 152 (4):536542.

Weine,Stevan, et al.1997. "A Family Survives Genocide." Psychiatry, 60 (1): 24-39.

Weschler, Lawrence. 1998a. A Miracle, A Universe: Settling Accounts With Torturers, revised edition. Chicago: University of Chicago.

Weschler, Lawrence. 1998b. Calamities of Exile: Three Non-Fiction Novellas. Chicago: The Uni. of Chicago Press.

Wiesenthal, Simon. 1998. The Sunflower: On the Possibilities and Limits of Forgiveness. revised edition. NY: Schocken Books.
Women's Commission for Refugee Women and Children/UNHCR. 1997. Guidelines on the Protection of Refugee Women: Synopsis. New York: The Commission, 5 pp. Wong, Jan. 1999. "Lunch with Wang Dan: The man who led a million protestors at Tiananmen Square". The Globe and Mail, June 2, 1999, c1. Yehuda, Rachel, et al. 1998. "Vulnerability and Posttraumatic Stress Disorder in Adult Offspring of HolocaustSurvivors". American Journal of Psychiatry, 155 (9): 1163-1171.

Young, Allan. 1990. "Moral Conflicts in a Psychiatric Hospital Treating Combat-Related Posttraumatic Stress Disorder (PTSD)". In Social Science Perspectives on Medical Ethics, edited by George Weisz, 6582. Kluwer Academic Publishers. Young, Allan. 1995. The Harmony of Illusions: Inventing Post-Traumatic Stress Disorder. Princeton University Press. a

\section{REPORTS}

Somall Refíges in Toronto:

\section{A Profile}

By Edward Opoku-Dapaah, 1995

ISBN $1.55014,278-\mathrm{x}, 130 \mathrm{pD}, \$ 12,95$

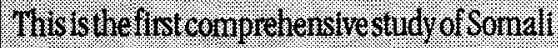
refinges in Toronto It examines he social residential and linguistic charrecteristic of Somalls, their particlpation in the local economy and he activiy or Somall commu My organizations. The report also contains valudble suggestons and recommendations conceming suitable and more efichent servige delven to this community.

- Cambodian Refugeses in Ontario: An Evaluation of Resettlement and Idaptation

By Janet Mclellan, 1995

ISBN 1-55014-267-4, 142 pP. $\$ 12.95$

This major swity of cambodian refugees in

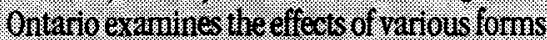

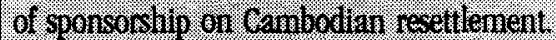

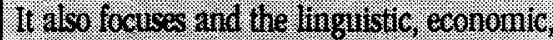

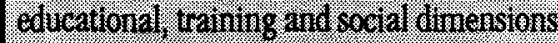

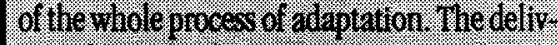

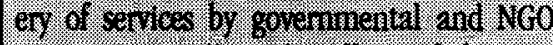

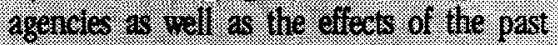

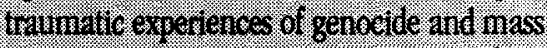

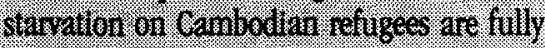
(1) 


\section{Call for Papers Refugee Return}

\section{Guest Editors : Peter Penz, and Alan Simmons,}

This issue of Refuge, Canada's periodical on refugees, will address the process of refugee return to their home countries. In a number of cases around the world, peace treaties and similar agreements following displacement-inducing conflicts have made this possible. Examples from the past decade are the return of Guatemalans from Mexico, of Mozambiquans from Malawi, of Chittagong hillpeople from India back to Bangladesh, and of Bosnians from other countries in Europe.

While refugee return seems to be the ideal solution to the refugee problem, it also opens up new problems. Are refugees forcibly returned or do they keep the choice to stay in the country of asylum? Is there a period of asylum residence after which retum becomes difficult for reasons of identification and new roots? Do returning refugees get land back if they owned land before their flight? Do they get the same property back or do they get alternative land elsewhere? Do nonreturning refugees get monetary compensation for their property? What happens to current occupants of property to which returning refugees are entitled? Are there discrepancies between legal entitlements and implementation? If there has been a change in the ethric composition of a refugee-origin area, are refugees reluctant to return to such an area? What kind of governmental and international assistance is needed and is being made available? How are the relations between returning refugees, those who stayed and those who moved into vacated property and areas working out? Is a conflict-resolution process required? In what way can local-development strategies alleviate or accentuate such conflicts? Are there lessons for the international refugeerights regime or for policies on refugee return?

Papers responding to questions such as these can be addressed either thematically or within particular case studies.

Contributions with abstracts and a short biographical note about the author are invited. They should be received no later than January 15, 2000. Papers should be typed, double-spaced, and referenced in the academic format. They should not exceed 16 pages or about 4000 words. Short papers of about 900 words are also welcome. Word-processed submissions may be sent on disc or by email.

On accepte aussi des articles en français. Le style doit conformer aux normes exigés pour les articles rédigés en anglais.

Deadline: January 15, 2000

Inquiries may be directed to:

Peter Penz, CRS Director and Associate Professor in Environmental Studies

Email: ppenz@yorku.ca

or

Alan Simmons, Associate Professor in Sociology

Email: asimmons@yorku.ca 